\title{
ELECTRONIC TRACKING OF POSTAL SERVICES
}

\author{
Žaklina Spalević, \\ Miloš llićn, \\ Milan Palević 3 \\ ${ }^{1}$ Singidunum University, \\ 32 Danijelova Street, Belgrade, Serbia \\ ${ }^{2}$ University of Pristina, \\ Faculty of Technical Science, \\ Kosovska Mitrovica, Serbia \\ ${ }^{3}$ University of Kragujevac \\ Faculty of Law, \\ Kragujevac, Serbia
}

\begin{abstract}
:
In modern times, posts worldwide are using new technologies to improve the existing services, develop new ones, and improve the delivery of mail, package, express and financial services. Such improvements have been achieved over years, based on different market demands and customers' evolving needs. In the era of electronic devices, the Internet and the possibility of real time monitoring has created a need for development of different electronic services that will be used in postal services. Electronic tracking of packages from the costumer and postal side is one of the most important postal services. This kind of service provides useful information about the current location of the package to both sides. This information can accelerate the package delivery process. This paper summarizes and presents different uses of electronic postal services for package tracking through technical and legal observation. The paper also presents different illegal uses of postal services and solutions for better protection in accordance with the law.
\end{abstract}

Key words:

electronic package monitoring, electronic postal services, postal abuse, GPS tracking.

\section{Acknowledgment}

This work has been supported by the Ministry of Education, Science and Technological Development of the Republic of Serbia within the projects TR 32023 and TR 35026.

\section{INTRODUCTION}

Over the past twenty years, significant steps have been made to improve postal services as well as increase trust in online postal transactions. While the impact of digitization is not new, the digital economy is entering a new phase that presents new challenges and opportunities. Digital tools are changing how companies are structured and how they communicate and sell. This has triggered the digital transformation of the postal industry. Some of them, such as broadband Internet, mobile and social networks are long-term trends that started at the turn of the century. Others, such as the "Internet of Things" or big data, embody a new wave that will increasingly impact e-postal strategies in the upcoming years.

In one study published by the Universal Postal Union (UPU) about four years ago, fifty-five different types of postal e-services were identified. All of them are currently offered worldwide (Corredera, 2012). 
Different postal services work in different ways, and demand different use of new technology solutions. One of them is Express Mail Service (EMS). EMS is a global brand designating the postal product with the fastest delivery. That is an international express postal service offered by postal-administration members of the UPU. These administrators created the EMS Cooperative in 1998 within the framework of the UPU to promote the harmonization and development of postal services worldwide. Posts in around 200 countries and territories worldwide offer this premium end-to-end service for documents and merchandise. Many transportation logistics firms offer similar accelerated services. Express and standard package and mail transportation must be finished in advance of the defined time period. All shipments must be preserved and delivered in their original form.

Another electronic service provided by postal institutions, which is connected with mail and packages transportation, is package tracking. Package tracking or package monitoring is the process of localizing containers, bags, and package post at different points of time. This process is important because it provides information about package origins and could predict time of delivery. Necessary information is collected during package sorting, storing in the warehouses, and delivering to the recipient. This kind of electronic or online service provides customers with the information about the route of a package and the expected date and time of delivery (Esser, 2011). Mail tracking is made possible through additional postal services. Those postal services require that the identity of a mail (packages) be recorded during various points of delivery. Such information provides proof of delivery to the sender, but it also enables the receiver to predict the time of delivery. (Joyce, 1893). To identify the location of the mail, two methods are in use worldwide. The first one involves reporting the arrival or leaving of the package and recording the identity of the package. Location, time, and status are parameters that represent package identity. The second approach is based on Global Positioning System (GPS) of vehicle tracking. This system is in use to locate the vehicle that contains the concrete package and record vehicle position in a real-time database (Dignan, 2007).

With development and massive use of the Internet and mobile devices, web-based package tracking is in use to automate customer service. Web-based tracking system provides the ability to track the status of a package in real time. Appropriate evidence of online tracking popularity is registered during the period from 1995 to 1999 . The number of web tracked packages in 1995 was 3.3 million a day (TNYT, 2000). Online package tracking became available for all major carrier companies. It was significantly improved by the appearance of websites that offered combined tracking for different mail carriers (Basu, 2010). With the rise of smart phones, package tracking mobile apps are used to send tracking info to customers' cell phones. Furthermore, mailing services are able to automatically detect tracking numbers in messages and provide real time location of the package to the user (Pogue, 2012).Package transportation is a complex and precise task for each postal company. The quality of service and customer satisfaction must always be on a higher level. Customers transport many illegal materials and products by this kind of services. Drugs, weapons, smuggled goods are just some of the products that can be found in packages that are transported through the postal transportation service. This and many other abuses of postal service are the problems for transportation companies. Because of that, posts must improve their services with each new day, and protect themselves and their customers from people who abused this type of service.

The first goal of this research is to provide information about postal tracking system from the customer and postal side. The second goal is to present the most important and most dangerous abuse of postal services. The third goal is to provide legal regulations in the fight against this kind of postal abuse.

\section{E-TRACKING OF POSTAL PACKAGES}

Package tracking is an integral part of a package delivery service that allows a customer to track goods that they have shipped or that have been shipped to them. The advent of the Internet has allowed commercial carriers to make it possible for customers to track their shipments online using a web-based service. Some businesses have taken package tracking a step further and integrated the package tracking functionality into their internal business systems. Based on the tracking system, the client could get information about delivery date and time, name of the recipient, the visual appearance of digitized signature of the recipient and etc.

For the most part, package tracking services operate on a package-by-package basis and require that a customer queries a carrier database with a package tracking number associated with the package to be tracked. Tracking number is alpha-numeric code, and this code consists of thirteen alphanumeric characters. This numeric code is divided into three groups of characters: 
- The first group consists of two characters, and these characters represent the type of a postal shipment.

- The second group consists of nine alphanumeric characters, and this group represents ordinal number of shipments.

- The third group consists of the last two alphanumeric characters, which represent a country where the package was shipped.

Some of examples are EE123456785US, RR123456785US and CP123456785US. This code contains check digit which shows whether EMS tracking number contains a mistype. A block of characters representing the country indicates the origin country of the shipment. Bags and containers in which the packages are dispatched must also be marked with code. This code consists of seventeen alphanumeric characters, which are divided into four groups.

- First six alphanumeric characters represent the ordinal number of bags or containers.

- Seventh alphabetic character represents the type of the bag or containers.

- Characters from eight to twelve represent ZIP code of dispatching post office.

- The last five numeric characters represent ZIP code of the receiving post office.

Different states can be assigned to the shipment which is being electronically monitored. Some of them are: reception, awarded, dumped report, return to sender, next delivery, etc. Each of the states provides information for all sides to whom the information is of importance. Three main participants can be observed in this kind of tracking or monitoring. Those are the sender, the receiver and the carrier. Each of them has specific reasons for package tracing. Other users include Transport Broker, Packaging Services, Collection and Delivery Services, Depot/Hub/Terminal operators, and Vehicle Drivers (Jakobs et al., 2000). Senders can be either companies or individuals. Individual senders will typically take the package to a collection office. Home collection could also be possible, and it should be possible to arrange this service though internet/WAP access. The sender would like the options of email confirmation of package delivery, and internet/WAP access to transit status and estimated time of arrival. Company senders want to receive as much status information as possible because this can be then provided to their customers, providing value added to their service. Likewise, delivery time reliability is important, as would be the ability to confirm that the package has been received by the appropriate individual.
All receivers should receive advanced shipment notification with the packages in transit given a numeric code to be used by both sender and receiver. In the case of individual receivers, the numeric code will usually be assigned by the sender. Individual receivers want to know when a package will arrive so that they can ensure that someone is there to receive it. Internet/WAP access and email messages can provide an attractive customer service. Depending on the nature of the business, size of companies and the supplier-customer relationship, the level of detail of package movements and status can vary as agreed between the sender and the receiver.

Companies providing express delivery, freightforwarding and logistics management will be the main proximate users. Their customers may have certain data requirements, ,but they will mainly want a high level of performance and services to be provided to them seamlessly and transparently (Jakobs et al., 2000). The carrier also requires regular feedback from moving transport units where possible. This information will comprise location and transport unit status, along with all the packages carried and their routing, destination and estimated time of arrival.

\section{Improvements in postal tracking systems}

Each post office worldwide has one important task, to provide the best possible service to its customers. New technologies are used to create location tracking systems to provide better quality of packages transportation. One of them is GPS. On a large scale, companies must track their vehicle fleets across the country or the world. GPS is the ideal tracking technology for tracking over large areas. To do this, every vehicle needs to be equipped with a GPS receiver. As the vehicle crosses the country, the GPS satellites track the truck's position. With GPS, the operator can request positioning at any time. In this way, the posts base station may contain information on the current shipment location and the expected time of arrival. This information will accelerate the delivery process. As a replacement for traditional bar codes on the packages, Radio Frequency Identification (RFID) tags can be used. RFID are small microchips that can be attached to consumer goods, cattle, vehicles and other objects to track their movements. RFID chips are passive and only transmit data if prompted by a reader. The reader transmits radio waves that activate the RFID chip. The chip then transmits information via a pre-determined radio frequency. This information is captured 
and transmitted to a central database (Stanivukovic and Markovic, 2014). In the past, RFID was used for little more than the evaluation of postal performance. This kind of tags is used in a small percentage of letters, and for the tracking of a small number of conveyances and vehicles. International Postal Corporation now monitors mailflow and mailboxes with RFID in over 50 countries (Stanivukovic and Markovic, 2014). There is even a postal RFID system that completely automates the whole process of mail delivery from accepting the package through classification and dispatching. This system has been successfully tested in Korea on the mailboxes. Another example of RFID use for the postal services is RFID posts stamps. Stamps RFID project is based on the implementation of passive RFID tag on the traditional postage stamp in order to establish RFID technology in function of stamps. Symbiosis like this provides an increase in the quality of postal services, and opens new opportunities for development of postal services (Stanivukovic and Markovic, 2014).

\section{ABUSE OF POSTAL SERVICES}

Package transportation companies and postal offices must provide high quality of service to customers so that they could be able to send whatever they want and where they want. In most cases, employee in the post office does not check the contents of the shipments. The customer has an obligation to report what he/she sends and what is the value of the shipment. This fact provides the space for different abuse of postal services. Some abuses are minor, while some can be classified as criminal offenses. Offenders use the government and private postal companies transport prohibited goods. Different examples of postal service abuse shall be further presented.

\section{Drugs transportation via postal service}

Every day, smugglers all over the world develop different ways to transport and distribute narcotics. Postal transportation service is just one of them. They use different ways for this kind of job. One way is to pack narcotics in small packages and send them to different locations for redistribution. In some cases, narcotics are packed in packages that look like different medications. Some of the examples of narcotics transportation via postal service are presented in continuation.

The transportation of narcotics using various packages systems has been exploited, and it continues to be a popu- lar method of transportation, because it is relatively safe and inexpensive. These packages systems are occasionally monitored by law enforcement, but not sufficiently enough. This type of investigation is difficult to prove and takes extensive investigative effort (DWN, 2014).

One example of drugs transportation via postal service is recorded in Philadelphia. Two brothers were distributing methamphetamine via Express Mail between the two cities. Inspectors discovered the men were secreting methamphetamine inside caulking tubes and transporting the tubes to Philadelphia via Express Mail (IDAT, 2002). As with many drug networks, dealers used the U.S. Mail along with other transportation methods to distribute narcotics and narcotics proceeds. After taking the brothers into custody, inspectors identified their conspirators who drove the methamphetamine from Winston-Salem, North Carolina, to Philadelphia. Inspectors additionally arrested another two conspirators.

Postal Inspectors and San Diego Narcotics Task Force agents arrested a man on May 16, 2002, for distributing anabolic steroids, ketamine, and other controlled substances via the U.S. Mail. The suspect advertised products and received orders via the Internet and then distributed the products by Express Mail or Priority Mail (IDAT, 2002). He allegedly distributed approximately $\$ 5,000$ worth of controlled substances per day to more than 300 customers across the country.

The discovery of large quantities of drugs being trafficked through the mail in Peru and Ecuador have led to crackdowns and mandates for reform, while in Florida authorities reported an unusually high level of drug interceptions in the mail in 2011 (Bargent, 2013).

Since recreational use of marijuana became legal in several countries, the number of pot-filled packages sent through the mail increase rapidly. In some cases, pot was packaged inside cans of corn and bags were hidden inside a hand-held vacuum. Others were shipped in heat-sealed packages to disguise the smell. The U.S. Postal service handles more than 155 billion pieces of mail a year and more than a billion of that in Chicago. Forty thousand pounds of pot were seized nationwide from the mail in 2014 (Goudie and Markoff, 2015).

Traffickers use the postal service for narcotic delivery because it is relatively cheap, timely, and the volume of packages works against detection. A large number of post offices across the U.S. country handling millions of packages each day. Employees are talking about a massive number of packages to even consider examining. Mailing narcotics also gives traffickers flexibility to 
expand their markets to areas where traditional drugdealing systems are less profitable or practical. Express Mail is the preferred method because dealers can move their drugs quickly and covertly and get the proceeds back in the same fashion.

\section{Illegal weapons and ammunition transportation}

Illegal firearms transportation through the postal transportation service is another abuse of this kind of services. For this kind of job, offenders use different techniques to mask firearms inside the packages. In some cases, they packed weapons or ammunition in specially designed packages in order to reduce suspicion on the interior of the package. The package must look like some familiar object, and be of the same length. The description of the contents of the package usually responds to a metal object. This is because the package goes through metal detector checks. If the weapon is huge, it will be disassembled into parts. Each part will be sent into a different to the same or different addresses. At the destination, recipient will receive all the parts, and will assemble a weapon.

One example from Seattle shows two brothers arrested in June for a scheme to ship firearms parts to Thailand have pleaded guilty in U.S. District Court in Seattle to conspiracy to illegally export firearms parts (Brock, 2013). In plea agreements, the brothers admitted that one of them, while living in Thailand ordered firearms parts he wanted to send overseas. Investigators say the gun parts were first sent to his brother's home in Bellevue. He then tried to disguise the shipments and send them on to Thailand. Brothers in one case shipped magazines for .45 caliber handguns, while labeling them, "vented steel case for electronic components" or "replacement springs and metal caps for bottling machine." Other shipments were labeled as "hobby parts" or "glow in the dark marker sets." The group is believed to be responsible for more than 240 shipments of restricted firearms components. The defendants did not ship any assembled firearms.

In Canada, criminals are using postal system to transport illicit goods including guns, grenades, dangerous chemicals. Pistols, rifles, ammunition, body armour and hand grenades are being shipped to Canada from abroad (Bronskill, 2013). Each of presented examples shows that illegal transportation of weapons via postal service is not so uncommon, and criminals will use this kind of service for their illegal jobs regardless of the consequences.
The use of postal services for the delivery of sold goods

In most cases, posts provide package delivery between private individuals. One of the most common abuses of postal services in such cases is that the user not specifying the appropriate shipment value, especially when the value of shipment is large. In many cases, the customer does not state the regular name of the item in the package. For example, customer could send medicals, or some chemicals which need to be appropriately packed and transported. In such cases, because of the price for such kind of transportation, customer states that the package contains some books, plastic or metal objects. Another problem appears when packages containing breakable things are not properly marked. In the case of damage on the items inside the package, the customer could not refund the money in the value of the object inside the package. From other hand reputation of the post may be compromised. One more common abuse of postal transportation services, especially the express mail services, is related to delivery of sold products in online shopping. In cases like this, posts do not have mechanism to check what is in packages and if the item in the packet is object of some illegal purchase. Buyers purchase some products online or by telephone shopping. That product can be smuggled or stolen by the other side. For such product customers pay the agreed amount to the seller's bank account. After transferring the agreed amount to the seller's bank account, the seller sends the purchased object through the postal service. It is not so unusual that seller sends smuggled object to the buyer, and demand the price for an item is paying to postal worker at the time of receipt.

\section{LEGAL REGULATIONS BEHIND POSTAL SERVICES}

All postal services and activities assigned to the posts are regulated by the law of postal services. Each country has adopted this law in accordance with their needs. In the Republic of Serbia, law of postal services regulates the provision of postal services ${ }^{1}$. Article three declares that postal services are services involving the receipt, transmission and delivery of postal shipments. The transfer of postal items means technological processes in the postal operator from the receiving stations to the city of delivery of postal items. Packages are the shipments packaged

1 The law of postal services, „Official Gazette of the RS“, № 18/2005, 30/2010 and 62/2014. Retrieved 20.02.2016; from http://www.posta. rs/dokumenta/lat/o-nama/zakon-o-postanskim-uslugama.pdf 
in a prescribed manner, which contain goods and other items and have the item or document accompanying the shipment, and description of contents inside the package. Pursuant to the Article 6, all postal operators are obliges to act in accordance with their specific conditions, to provide inviolability of postal items and confidentiality of data. The principle of inviolability of postal items may be violated only in cases and under conditions stipulated by law. This means that if the some shipment or data about some customer are under the criminal investigation, those data must be forwarded to the legal authorities.

Article 29 stipulates which postal shipments are forbidden for sending or receipt, transmission and delivery This article bans shipment of narcotics, except in the case when the recipient and the sender are authorized by law for drugs traffic, or are authorized for their use. In special cases, in our country and abroad, different government services and agencies could define rights and obligations applicable to postal services. Posts have the right to create their policies about the work and service provision, which must be in accordance with the law. In the U.S., the United States Postal Inspection Service (USPIS) is one of the oldest law enforcement agencies. Its mission is to protect the Postal Service, its employees, and its customers from crime and to protect the nation's mail system from criminal misuse. Postal Inspectors apply over 200 federal laws in investigations of crimes that may adversely affect or fraudulently use the U.S. Mail, the postal system or postal employees. The USPIS has the power to enforce the USPS monopoly by conducting search and seizure raids on entities they suspect of sending non-urgent mail through overnight delivery competitors. The Postal Service in U.S. and other countries demands an unwavering commitment to strong ethical values and principled decision making from all of its employees. All postal employees are required to place loyalty to the Constitution, the laws and ethical principles above private gain. To ensure that every citizen can have complete confidence in integrity, each postal employee must respect and adhere to the principles of ethical conduct set.

\section{CONCLUSION}

Posts all over the world provide different services to their customers. Posts have advanced in the provision of services over years. Different new services have been introduced with the aim to provide better. In today's modern world, many of the postal services are related to the Internet and different other electronic devices. The purpose has remained the same, to provide as much as possible better and faster service to their customers.
Electronic tracking of packages during the transportation of the shipment provides different advantages to the customer and to the posts. Posts in different countries have different demands and technical solutions for electronic packages monitoring and tracking. Their common feature is that they cooperate with ICT technicians to provide better shipment tracking system.

On the other hand, malicious users, criminals, drug dealers and arms smugglers use postal services in their illegal activities on a daily basis. To prevent such criminal abuses, posts must provide better package control, and must cooperate with legal agencies and police offices. Only under such conditions, it is possible to ensure full security of their services.

\section{REFERENCES}

Bargent, J. (January, 2013). Criminals Used Mexican Postal Service to Move Drugs and Arms. InSight Crime - Investigation and Analysis of Organized Crime.

Basu, S. (August, 2010). 10 Package Tracking Websites for Alternative Ways to Track Your Shipments. Retrieved December 26. 2015. from http://www. makeuseof.com/tag/10-package-tracking-websitesalternative-ways-track-shipments/

Brock, T., (October, 2013). Two brothers plead guilty to illegally shipping gun parts to Thailand. Retrieved January 18. 2016. from http://q13fox.com/2013/10/22/ brothers-plead-guilty-to-illegally-shipping-gunparts-to-thailand/

Bronskill, J. (January, 2014). Criminals using Canada Post to transport illicit goods - including a rocket launcher - RCMP report says. National Post.

Corredera, D. (2012). Measuring postal e-services development, A global perspective. UPU, Berne, 1-20.

Dignan, L. (2007, February) FedEx couples Google Earth with active package tracking. Retrieved February 21. 2016. from http://www.zdnet.com/article/ fedex-couples-google-earth-with- active-packagetracking/

DWN. (May, 2014). How to Legally Accept a Drug Package as Per Police and Prosecutors. Retrived January 18. 2016. from http://darkwebnews.com/helpadvice/legally-accept-drug-package-per-police prosecutors/\#comments.

Esser, M. (2011). Industry Developed Temperature Tracking Device for Packages May Have Climate Metrology Applications NIST Tech Beat.

Goudie, C. \& Marcoff, B. (November, 2015). MAILING MARIJUANA: OFFICIALS REPORT SPIKE IN POT-LADEN PACKAGES. EYEWITNESS NEWS. 
IDTA. (2002). Illegal Drugs and Trafficking. Annual Report of Investigations, United States Postal Inspection Service. 26-28.

Jakobs, K., Williams, R., Graham, I., \& Wallbaum, M. (2000). DESIGNING AN OPEN TRACK \& TRACE SYSTEM-THE SOCIO-ECONOMIC CONTEXT. RWTH Aachen, University of Edinburgh (Hrsg.), Aachen, Edinburgh, ohne Jahr. 1-8.

Joyce, H. (1893). The History of the Post Office from its Establishment down to 1836. London: R. Bentley.

Pogue, D. (August, 2012). An E-Mail Service With Lots of Smarts. Retrieved December 26. 2015. from http:// www.nytimes.com/2012/08/09/technology/personaltech/outlookcom-an-e-mail-service-with-lots-ofsmarts-state-of-the-art.html?_r=0
Stanivuković, B., \& Marković, D. (2014). RFID U FUNKCIJI POŠTANSKE MARKE-ČIPOVANJE POŠTANSKIH POŠILJAKA. In XXXII Simpozijum o novim tehnologijama u poštanskom i telekomunikacionom saobraćaju - PosTel, 2. i 3. decembar 2014 (pp. 3-14), Beograd.

TNYT - The New Yourk Times. (February, 2000). U.P.S. Results Meet Forecast, But Fail to Impress Investors. Retrieved December 15. 2015. from http://www.nytimes.com /2000/02/01/business/ups-results-meetforecast-but-fail-to-impress-investors.html 